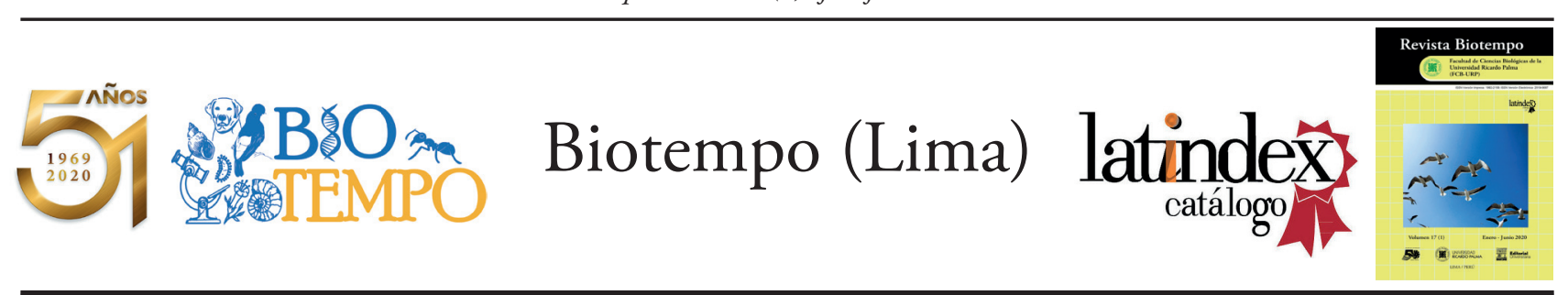

REVIEW ARTICLE / ARTÍCULO DE REVISIÓN

NATURAL COMPOUNDS TO REDUCE THE BACTERIAL LOAD IN THE ORAL CAVITY: A REVIEW ARTICLE

\title{
COMPUESTOS NATURALES PARA REDUCIR LA CARGA BACTERIANA DE LA CAVIDAD ORAL: UN ARTÍCULO DE REVISIÓN
}

\author{
Thaináh Bruna Santos-Zambrano ${ }^{1,2, *}$; Rubén Jaime-Szwom ${ }^{2} \&$ Ricardo Sergio Almeida ${ }^{3}$
}

$1^{*}$ Departamento de Patología, Universidad San Gregorio de Portoviejo, Ecuador. E-mail: thainahbruna@gmail.com

2 Departamento de Odontología, Instituto Universitario Italiano de Rosario (IUNIR), Argentina. E-mail: endodoncia. iunir@gmail.com

3 Departamento de Microbiología, Universidad Estatal de Londrina, Brasil. E-mail: rikodonto@gmail.com

*Corresponding author: thainahbruna@gmail.com

\begin{abstract}
Currently, there is a wide range of pharmaceutical products that offer great benefits for the treatment of various oral diseases. Most of these products are of synthetic origin with antibacterial properties but there are the numerous side effects associated with their use. An alternative is the use of natural products from plants and insects in the reduction of the bacterial load of the oral cavity as chamomile (Chamaemelum nobile (L.) All.), cocoa (Theobroma cacao L.), aloe (Aloe vera L.), moringa (Moringa oleifera Lam.), oregano (Origanum vulgare L.), coconut (Cocos nucifera L.), garlic (Allium sativum L.), clove (Syzgium aromaticum L.), cardamom (Elettaria cardamomum L.), stevia (Stevia rebaudiana Bertoni), honey bee and propolis, addressed in this literature review. This review attempts to address the use of different natural compounds in reducing the bacterial load of the oral cavity. It can be concluded that there are several studies about the effects of natural products on the part of man in medicine, where there are a large number of works and publications related to natural substances with active ingredients in reducing the bacterial load of the oral cavity.
\end{abstract}

Keywords: Dentistry - Microorganism - Natural products - Phytopharmaceuticals

\section{RESUMEN}

Actualmente, existe una amplia gama de productos farmacéuticos que ofrecen grandes beneficios para el tratamiento de diversas enfermedades orales. La mayoría de estos productos son de origen sintético con propiedades antibacterianas, pero existen numerosos efectos secundarios asociados con su uso. Una alternativa es el uso de productos naturales de plantas e insectos en la reducción de la carga bacteriana de la cavidad oral como la manzanilla (Chamaemelum nobile (L.) All.), el cacao (Theobroma cacao L.), el aloe (Aloe vera L.), la moringa (Moringa oleifera Lam.), el orégano (Origanum vulgare L.), coco (Cocos nucifera L.), ajo (Allium sativum L.), clavo (Syzgium aromaticum L.), cardamomo (Elettaria cardamomum L.), stevia (Stevia rebaudiana Bertoni), miel de abeja y propóleos, abordados en esta revisión de la literatura. Esta revisión 
intenta abordar el uso de diferentes compuestos naturales para reducir la carga bacteriana de la cavidad oral. Se puede concluir que existen varios estudios sobre los efectos de los productos naturales por parte del hombre en la medicina, donde hay una gran cantidad de trabajos y publicaciones relacionadas con sustancias naturales con ingredientes activos para reducir la carga bacteriana de la cavidad oral.

Palabras clave: Fitofarmacéuticos - Microorganismos - Odontología - Productos naturales

\section{INTRODUCTION}

The microbiota of the oral cavity is made up of thousands of microorganisms, including bacteria, fungi, and viruses, which find their ideal niche in it. The presence of pathogenic bacteria and their products of metabolism interfere with the homeostasis of the oral tissue, which leads to the development of diseases such as caries, periodontitis, and respiratory diseases (Mayta et al., 2012; Falsetta et al., 2014; Jakubovics, 2015).

Various investigations, such as epidemiological studies, laboratory tests, and animal tests, confirm the association between Streptococcus mutans Clarke 1924, dental caries, and poor hygiene of the oral cavity. S. mutans is a Grampositive bacterium with coconut morphology, with optional anaerobic respiration, and presents lactic acid as the final product of its fermentation. The excessive production of this acid by this coconut in the presence of carbohydrates causes a drop in the $\mathrm{pH}$ (below 5.0) and the demineralization of dental tissues, giving rise and development to caries. This disease is multifactorial and global in scope and affects children and adults. In some parts of the world, it is endemic due to the minimal hygiene instruction of the population and the poor local conditions (non-fluoridated water, lack of adequate dental treatment, and a cariogenic diet) (Akthar et al., 2014; Dalmasso et al., 2015; Oda, 2015). S. mutans is also associated with cases of non-oral infection such as bacterial endocarditis. Therefore, it is crucial to decrease the number of bacteria in the saliva before invasive procedures, avoiding the appearance of bacteremia, and the consequent endocarditis (Lambert et al., 2001; Shan et al., 2011; Ricatto et al., 2014; Kaur et al., 2015).

Another important microorganism present in the oral cavity is the Enterococcus faecalis Orla-Jensen 1919 bacteria. It is an optional Gram-positive and anaerobic coco microorganism. This bacterium can colonize a wide range of habitats, such as the gastrointestinal tract and the vagina. In the oral cavity, it is free in saliva, and, when present in the root canals, it is associated with failure and the need for endodontic retreatment (Wang et al., 2012; Aparicio et al., 2019; Bernardino et al., 2019). Improvements in biological material collection techniques and molecular identification methods helped reveal this microorganism in root canals (Sedgley et al., 2006; Alarcón et al., 2016; Escalante \& Martínez, 2020; Moreno et al., 2020). E. faecalis has some mechanisms that aid in survival and permanence within the tooth, where the decaying dental pulp creates an extremely inhospitable environment. These mechanisms include high nutritional adaptation, survival in an extremely alkaline environment, and mobility to penetrate deep into the dentinal tubules (Gursoy et al., 2013; Bumb et al., 2014; Zhang et al., 2015; Reyes et al., 2018).

The use of a toothbrush, paste, and dental floss combined with a correct oral hygiene technique are among the options found by humans for the mechanical elimination of pathogenic microorganisms. However, some patients cannot reach certain places or even lack the manual dexterity necessary to carry out effective oral hygiene, do not satisfactorily eliminate microorganisms, and, consequently, favor the evolution of pathologies (Almas \& Al, 2004; Gunsolley, 2010; Al \& Kasi, 2012). As an alternative to this problem, mouthwashes are recommended, since they can reach places that are difficult for the patient to access, in addition to destabilizing and helping to eliminate microorganisms (Santos, 2003; Xu et al., 2011; Gonçalves, 2013).

All these factors result in the current market having a wide range of pharmaceutical products that offer great benefits for treating various oral diseases. Most of these products are of synthetic origin with healing properties. There is no report of products intended to decrease the bacterial load of the oral cavity, only pharmaceutical forms manufactured for the treatment of inflammation of the oral tissues (Shon et al., 2004; Enrile de Rojas \& Santos, 2005; Rasooli et al., 2009).

The use of natural compounds as a treatment agent for different local and systemic disorders has been practiced 
for thousands of years in various countries, mainly in eastern countries. According to the World Health Organization (WHO), $80 \%$ of the world population depends on traditional herbal medicine for their primary health needs (Borba \& Macedo, 2006; García et al., 2007).

The use of certain plants with natural medicinal properties has always been used to produce or use some drugs related to current therapeutics. In pharmaceutical laboratories, some plants undergo some processes such as extraction, purification, among others, and then they are used for some pharmaceutical functions (Dagli et al., 2015; Jakubovics, 2015). In addition to plants, compounds generated by insects such as bees have also been used in the development of natural medicines.

The aim of this research is to review the use of compounds natural in reducing the bacterial load of the oral cavity.

Some natural compounds to reduce the bacterial load of the oral cavity are presented below:

\section{Chamomile (Chamaemelum nobile (L.) All.)}

Chamomile has been considered since past times as a natural and traditional medicinal plant. It can be antiinflammatory and antioxidant, thus helping relaxation, disinflammation and also acts as a sedative, having reasonable control of bacteria and other microorganisms in regards to the oral cavity. It has been proven that it reduces signs of gingivitis, such as inflammation and bleeding at the gum level (López, 2015; Borja, 2017). Chamomile is titled as an ideal natural medicine due to its composition since this product does not produce stains; taste alterations, are non-toxic and can be used at all ages, both in children, the elderly, and pregnant women (López, 2015).

The antibacterial effect that chamomile has on the bacteria $S$. mutans, has been raised through studies for that it can be used as a mouthwash. Since it is easily accessible, low cost, and it can be found within everyone's reach, and it does not have harmful side effects for those who choose it possible occupy chamomile as a natural medicine (Schencke et al., 2016; Fazio et al., 2010).

\section{Cocoa (Theobroma cacao L.)}

One of the most predominant pathologies in the oral cavity due to $S$. mutans is caries and periodontal disease. Dentistry has been in charge of investigating among numerous natural agents to decrease the bacterial effects within the oral biofilm, among them cocoa complies with properties against acids and glucan synthesis, allowing its decrease and favoring the bacteriostatic qualities of the mentioned agent (Mariani et al., 2010).

The properties of cocoa focus on the action that the extract of her seeds and powder can generate in dental plaque. Attributing the leading role to the polyphenols in cocoa that are responsible for the inhibitory activity on the glucosyltransferase enzyme, showing bacteriostatic behavior that reduces to some extent, the action of the $S$. mutans (Mariani et al., 2010).

\section{Aloe (Aloe vera $\mathrm{L}$.}

Taking into account the anti-inflammatory, antimicrobi$\mathrm{al}$, and tissue healing effects of aloe vera, its application in dentistry is extensive. Periodontal disease and dental caries are multifactorial pathologies of high prevalence worldwide. They have an infectious component with tissue destruction; in this sense, the regenerative effect has been demonstrated in soft and hard tissues (Boonyagul et al., 2013). On the other hand, scarring requires the absence of microorganisms. Therefore, the use of this plant could solve pathologies such as periodontal disease, loss of dentin tissue, bone tissue after tooth extraction, and other pathologies, in an economical and relatively safe way (Moreno et al., 2011; Boonyagul et al., 2013).

More than seven decades after the first publication of the application of Aloe vera in Dentistry, scientific work is scarce, as periodontal disease is the most studied. According to the results, the products or derivatives of this plant could be a pharmacological alternative for many oral diseases of an infectious, inflammatory, and tissue loss nature (Moreno et al., 2011).

\section{Moringa (Moringa oleifera Lam.)}

Although research on herbal medicine applied in dentistry is scarce, moringa offers excellent potential for applications in diseases such as dental caries and periodontal disease, highly morbid pathologies, where their ubiquity makes it one of the problems of most important public health worldwide. In this sense, herbal formulations with antiseptic and antiplaque action play an essential role in the prevention of these diseases (Dinesh, 2016). Both dental caries and periodontal disease have their origin in the bacterial biofilm, an entity formed by the colonization and accumulation of microorganisms in the microflora, immersed in a matrix of glucans. $S$. mutans produces glucosyltransferase, an enzyme that synthesizes these glucans, essential for the adherence and 
survival of biofilm microorganisms, since they form a barrier that prevents the diffusion of acids generated by these bacteria, in addition to creating poor environment oxygen (Dinesh et al., 2016; Fazio et al., 2019).

\section{Oregano (Origanum vulgare L.)}

Oregano is an aromatic plant. This plant has an essential oil that is carvacrol and thymol. This plant is well known commercially for being used as a species, seasoning, and medicinal properties. It also has antibacterial, antifungal, antiparasitic, antimicrobial, and antioxidant properties. The oil that comes from this plant has an antimicrobial effect against gram-positive and gram-negative bacteria. This antibacterial effect is because oregano has a high content of polyphenolic compounds (Albado et al., 2001; Rasooli et al., 2009).

Earlier it was mentioned that oregano contains compounds such as carvacrol and thymol; these compounds affect the permeability of the cell membrane. The effect on phospholipids causes changes in the composition of fatty acids (Pérez et al., 2020).

Studies carried out to verify the effectiveness of oregano against dental caries show the following (Karadaĝliogllu $e t$ al., 2019; Liu et al., 2019):

"The findings of this study show that $O$. vulgare (Oregano) at low concentrations (1\%, 5\%, and 10\%) do not have any antibacterial effect on the in vitro growth of S. mutans. However, at high concentrations (20\%, 40\%, $60 \%, 80 \%$, and $100 \%$ ), they have an antibacterial effect against the growth of $S$. mutans. So it was determined that the minimum inhibitory effect was achieved at $20 \%$ corresponding to $4 \mathrm{~g}$ of oregano in $200 \mathrm{ml}$ of water.

According to the results of the study, the higher the dilution of oregano concentration, the greater the inhibition halos (Karadaĝlioĝlu et al., 2019; Liu et al., 2019).

\section{Coconut (Cocos nucifera L.)}

Coconut oil has antibacterial properties as a natural product. Also, it has antibiotic properties that come from a high concentration of lauric acid, which is characterized by the increased antibacterial and antiviral properties of the body. For this reason, when applied, coconut oil will be more effective than any other synthetic product, since it can minimize consequences, acting as an inhibitor of $S$. mutans, as the main bacteria involved in the generation of dental caries (Joy et al., 2019).
An in vitro experimental research carried out (Lambert, 2001) in which coconut oil was applied to a culture of S. mutans strains, to identify the inhibitory effect by measuring inhibition halos, found the following:

"In a research study, homemade coconut oil was made, in which a diluent was used to obtain different concentrations of $50 \%, 75 \%$ and $100 \%$, which is pure oil, whose average inhibition results were $12.96 \mathrm{~mm}$ for $100 \%$ concentration, $12.05 \mathrm{~mm}$ at $75 \%$ concentration and $11.17 \mathrm{~mm}$ at $50 \%$ concentration, which shows that S. mutans turns out to be "Sensitive or inhibited" when presenting halos of inhibition greater than $8 \mathrm{~mm}$ ".

Streptococcus mutans was shown to be sensitive to coconut oil in concentrations of $50 \%, 75 \%$ and $100 \%$, taking into account that there are no significant differences between the inhibitions produced by the three different concentrations (Joy et al., 2019).

\section{Garlic (Allium sativum L.)}

In a study in India, he stated that an abscessed tooth is an infection with unsupportable pain that occurs when these bacteria enter the root of the tooth through a cavity or crack between them. These cavities occur when certain substances or bacteria, whether external or internal, enter between these cracks and make your enamel susceptible and weak. The symptoms are closely related to redness, burning, and swelling of the gums (Saha $\&$ Bandyopadhyay, 2019).

The mixture of the flavonoids that have sulfur in garlic heals a specific part of the swelling and relieves pain. It contains a substance called Allicin that its action is to function as a natural antibiotic that can make it possible to destroy some other bacteria. Garlic is a local anesthetic that gives pain relief by numbing the infected area and aiming to reduce pain temporarily (Saha \& Bandyopadhyay, 2019).

Garlic, when used as a natural agent, can be used alone or mixed with other natural ingredients to make a treatment with improvement and effectiveness. There are several ways on how to apply garlic (topical use), place the garlic clove in direct contact with the infected area, rinse with garlic water, fill garlic powder, garlic paste and salt with hot water as an antiseptic property, garlic ointment as an antibiotic, garlic and cloves as a pain reliever and garlic paste and Curcuma (Saha \& Bandyopadhyay, 2019). 


\section{Clove (Syzgium aromaticum $\mathrm{L}$.)}

According to Radünz et al. (2019) deduced that thanks to the small properties provided by cloves, a natural and effective remedy could be obtained to combat cavities and prevent the severe accumulation of tartar and to combat bad breath. To keep the teeth and the entire oral cavity healthy, we must maintain adequate hygiene and, for this, more effectively, natural agents such as rinsing cloves against dental caries. Cloves have excellent antiseptic properties (Radünz et al., 2019).

Most toothpaste and rinses contain ingredients that could be harmful to the oral cavity, such as alcohol, parasites, and sulfates. This natural agent serves to complete the cleaning of the mouth and to provide good breath after the correct brushing of teeth. With this, it can facilitate the elimination of microorganisms, either $50 \%$ of which cause cavities, bad breath, and inflammation of the oral cavity. However, this can be supplemented by its help with alcohol and natural ingredients such as cloves (Radünz et al., 2019).

Clove is an aromatic spice originating from Indonesia, and its high antiseptic power prevents cavities and any oral infection, it has analgesic properties for toothache. Its intense smell is a remedy for bad breath and is antiinflammatory for the gums and prevents gingivitis (Radünz et al., 2019).

\section{Cardamom (Elettaria cardamomum $\mathrm{L}$.}

Cardamom is an aromatic condiment with highly valued medicinal agents since it helps digestion, it is a remedy for lack of salivation, a natural antiseptic, and a remedy for halitosis and bacteria that cause cavities. This plant is usually harvested in countries of India, it is a family of ginger, and therefore it grows and has excellent roots (Maheswari et al., 2020).

It has large flowers and green leaves, its seed has a bitter taste, but it is edible since it has its benefits as it is a natural medicine for bad breath since this plant is a source of cineole, this is a natural antiseptic that helps kill bacteria that cause cavities (Maheswari et al., 2020).

\section{Stevia (Stevia rebaudiana Bertoni)}

Stevia is used as pills in natural medicine, in the medicine of Asian countries, it is considered to be very good to fight allergies, increase defenses, control cholesterol and is also a natural treatment for hypertension, diabetes, obesity, caries and oral health. On the other hand, in the
Mediterranean and American countries, its properties are less known, because people are unaware of its properties and its healing capacity, it is also known as the sweet herb of Paraguay. It is edible, and we find it as a sunflower family (Tiwari et al., 2018).

It has effective agents for treatments of oral conditions such as caries, the extracts it has been lethal for the bacteria that cause caries and dental plaque. These discoveries are important not only because these microorganisms do not grow because there is no sugar, but also because the activity is bactericidal, that is, it kills the bacteria that drive these diseases. This opens a handy field for stevia in other pharmacological applications. It can be used as the main compound in mouthwashes, toothpaste, among others, due to its high content of vitamin C (Tiwari et al., 2018).

\section{Honey bee}

Bee honey has essential medicinal properties so much so that since ancient times they have been considered for helping in treatments against infections caused by both bacteria and fungi. Manuel de la Rosa and José Prieto maintain that (De la Rosa \& Prieto, 2010):

"Honey is a natural product, made by bees based on the nectar of flowers, bees enrich and transform this nectar with substances that they generate in their bodies, and deposit it and store it in the combs where they mature.t presents an acidic $\mathrm{pH}$ ranging from 3.2 to 4.5 ".

The antibacterial characteristics that it presents are mainly due to its osmolarity. Its content is related to the demand for water present, its low $\mathrm{pH}$, among other specific components that each plant possesses, these will transfer its qualities and elements positive and essential to the nectar collected by bees (Romero, 2013).

The honey has been investigated against $S$. mutans infections, dental plaque and caries, gingivitis and halitosis. Honey was also useful in preventing side effects associated with treatment of cancers of the head and neck, namely, radiation induced mucositis, xerostomia and poor wound healing (Ramsay et al., 2019).

\section{Propolis}

Sánchez (2017), defines propolis as being: "distinguished by being a resinous substance, bitter at times with a pleasant and sweet aroma, propolis, performs an antibacterial action such as inactivating the membrane potential and inhibiting protein synthesis as for bacteria, it is concerned." 
When talking about the bacterium S. mutans (the primary driver of caries), the focus is on damage to the plasma membrane. The antibacterial action that propolis develops consists of exclusive chemical composition in flavonoids such as apigenin, identified by having the inhibitory quality of glucosyltransferases in bactericidal response, avoiding the synthesis of glucans since these can affect the oral microbiota (Sánchez, 2017). This bacterium mentioned above has acidogenic properties which promote the production of extracellular and intracellular polysaccharides, under the effects of propolis (Mayta et al., 2012).

\section{Antimicrobial-inhibitory effects of compounds natural on microorganisms in the oral cavity.}

In Table 1, it is shown the antimicrobial inhibitory effects of natural compounds from plants and insects on microorganisms, being that different parts of the plants (fruit, endosperm, seed, bulb, shell, stem and leaves) are extracted with chemical or natural solvents, in the control of microorganisms, in research in vivo and in vitro.

Table 1. Antimicrobial-inhibitory effects of compounds natural on microorganisms in the oral cavity.

\begin{tabular}{|c|c|c|c|c|}
\hline $\begin{array}{l}\text { Plant/part or } \\
\text { Compounds } \\
\text { natural }\end{array}$ & Extract & Micro-organism control & Application & References \\
\hline $\begin{array}{l}\text { Cymbopogon } \\
\text { citratus Spreng/ fruit }\end{array}$ & Ethanol & $\begin{array}{l}\text { Enteriobacteriacae, Staphylococcus } \\
\text { aureus Rosenbach, } 1884\end{array}$ & in vitro & $\begin{array}{l}\text { (Ramsay et al., } \\
\text { 2019) }\end{array}$ \\
\hline $\begin{array}{l}\text { Allium sativum L./ } \\
\text { Bulb }\end{array}$ & Ethanol & $\begin{array}{l}\text { Enteriobacteriacae, } \\
\text { Candida spp. Berkhout, } 1923\end{array}$ & in vitro & $\begin{array}{l}\text { (Ramsay et al., } \\
\text { 2019) }\end{array}$ \\
\hline $\begin{array}{l}\text { Thymus vulgaris L.I } \\
\text { leaves }\end{array}$ & $\begin{array}{l}\text { Thymol, } \\
\text { Linalol } \\
\text { Carvacrol }\end{array}$ & $\begin{array}{l}\text { Listeria monocytogenes Pirie, } 1940, \\
\text { Escherichia coli Escherich, } 1885, \\
\text { S. typhimirium Rosenbach, } 1884 \\
\text { S. aureus }\end{array}$ & in vitro & $\begin{array}{l}\text { (Radünz et al., } \\
\text { 2019) }\end{array}$ \\
\hline $\begin{array}{l}\text { Verbena } \\
\text { officinalis L./ leaves }\end{array}$ & $\begin{array}{l}\text { Borneol } \\
\text { Geraniol }\end{array}$ & $\begin{array}{l}\text { S. aureus, } \\
\text { E. coli, } \\
\text { S. typhimirium, } \\
\text { L. monocytogenes }\end{array}$ & in vitro & $\begin{array}{l}\text { (Rasooli et al., } \\
\text { 2009) }\end{array}$ \\
\hline $\begin{array}{l}\text { Libanothamnus } \\
\text { neriifolius Ernst / } \\
\text { leaves }\end{array}$ & Oil & $\begin{array}{l}\text { S. aureus, } \\
\text { Enterococcus faecalis Orla-Jensen 1919, } \\
\text { E. coli, } \\
\text { Klebsiella pneumoniae Trevisan 1885, } \\
\text { Pseudomonas aureginosa Schroeter, } \\
\text { 1872, } \\
\text { Candida albicans Berkhout, } 1923 \text {, } \\
\text { Candida krusei Berkhout, } 1923\end{array}$ & in vitro & (Reyes et al., 2018) \\
\hline $\begin{array}{l}\text { Theobroma cacao L./ } \\
\text { shell. }\end{array}$ & Oil & $\begin{array}{l}\text { P. aeruginosas, } \\
\text { Proteus sp. Hauser } 1885 . \\
\text { Enterobacter sp., E. coli, } \\
\text { Pseudomonas putida Trevisan } 1889\end{array}$ & in vitro & (Romero, 2013) \\
\hline
\end{tabular}


Continua Table 1

\begin{tabular}{|c|c|c|c|c|}
\hline Aloe vera L./gel & Glycerol & $\begin{array}{l}\text { Helicobacter pylori Marshall et al. } 1985 \text {, } \\
\text { E. coli, } \\
\text { E. faecalis, } \\
\text { S. aureus, } \\
\text { Streptococcus mutans Clarke } 1924\end{array}$ & in vitro & $\begin{array}{l}\text { (Saha \& } \\
\text { Bandyopadhy, } \\
\text { 2019) }\end{array}$ \\
\hline $\begin{array}{l}\text { Cocos nucifera L./ } \\
\text { endosperm }\end{array}$ & Oil & $\begin{array}{l}\text { Listeria ivanovii, } \\
\text { L monocytogenes }\end{array}$ & in vitro & (Sánchez, 2017) \\
\hline $\begin{array}{l}\text { Moringa oleifera } \\
\text { Lam./Seed }\end{array}$ & Water & E. coli, $\beta$-Lactamasas & in vivo & (Santos, 2003) \\
\hline $\begin{array}{l}\text { Stevia rebaudiana } \\
\text { Bertoni/ leaves }\end{array}$ & Ethanol & $\begin{array}{l}\text { S. sanguinis White \& Niven, } 1946 \\
\text { Actinomyces viscosus (Howell et al., } \\
\text { 1965) Georg et al., } 1969 .\end{array}$ & in vitro & $\begin{array}{l}\text { (Sedgley et al., } \\
2006)\end{array}$ \\
\hline $\begin{array}{l}\text { Salvadora persica L./ } \\
\text { stem }\end{array}$ & Water & $\begin{array}{l}\text { S. mutans } \\
\text { Lactobacillus spp. Beijerinck } 1901 \\
\text { S. aureus }\end{array}$ & in vivo & $\begin{array}{l}\text { (Schencke et al., } \\
\text { 2016) }\end{array}$ \\
\hline Juglans regia L./ stem & $\begin{array}{l}\text { Methanol } \\
\text { Ethanol } \\
\text { chloroform } \\
\text { Acetone } \\
\text { Water }\end{array}$ & $\begin{array}{l}\text { S. mutans, } \\
\text { Porphyromonas gingivalis Coykendall et } \\
\text { al., } 1980\end{array}$ & in vivo & (Shan et al., 2011) \\
\hline $\begin{array}{l}\text { Camellia sinensis L./ } \\
\text { leaves }\end{array}$ & $\begin{array}{l}\text { Polyphenol } \\
\text { Ethanol }\end{array}$ & S. mutans & in vitro & (Shon et al., 2004) \\
\hline Morus alba L./ leaves & Ethanol & $\begin{array}{l}\text { S. mutans, } \\
\text { Actinobacillus actinomycetemcomitans } \\
\text { Klinger, 1912, } \\
\text { P. gingivalis, } \\
\text { Prevotella intermedia (Holdeman \& } \\
\text { Moore 1970) Shah \& Collins } 1990 \text {, } \\
\text { Streptococccus mutans Clarke } 1924 \text {, } \\
\text { Streptococcus mitis, } \\
\text { S. sanguinis, } \\
\text { Actinomycete viscosus (Howell et al., } \\
\text { 1965) Georg et al., 1969, Lactobacillus } \\
\text { acidophilus Johnson et al., } 1980 \\
\text { Lactobacillus delbrueckii subsp. lactis } \\
\text { (Orla-Jensen 1919) Weiss et al. } 1984\end{array}$ & in vitro & $\begin{array}{l}\text { (Tiwari et al., } \\
\text { 2018) }\end{array}$ \\
\hline $\begin{array}{l}\text { Mentha spicata L./ } \\
\text { leaves }\end{array}$ & Oil & S. mutans & in vivo, in vitro & (Wang et al., 2012) \\
\hline
\end{tabular}


Continua Table 1

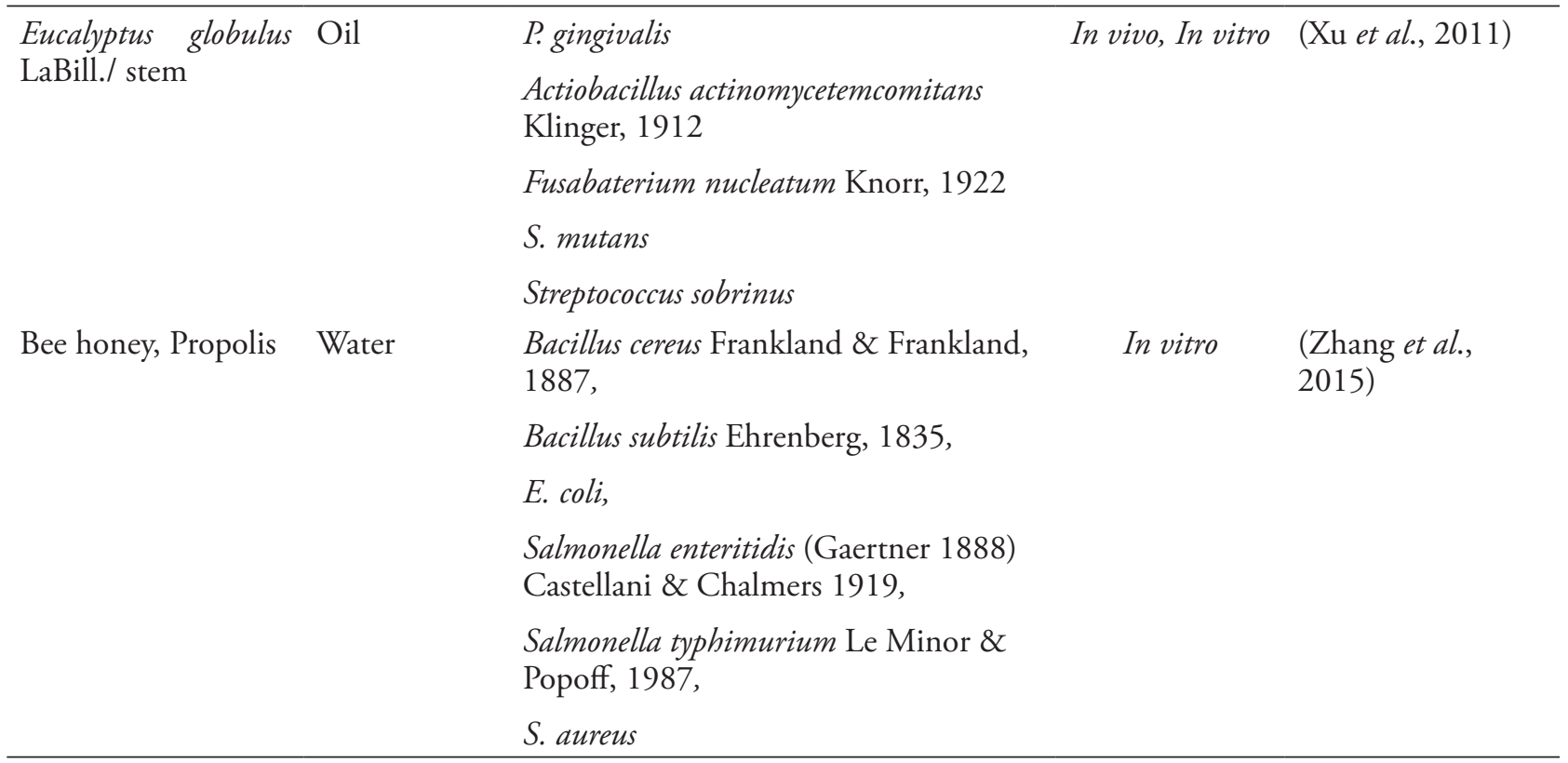

\section{CONCLUSIONS}

According to the literature, it can be concluded that there are several studies concerning the effects of natural products on the part of man in medicine, where there are a large number of works and publications related to natural substances with an active ingredient of biological interest with phytopharmaceuticals. However, in dentistry, there is also this trend, more than a few publications that allow a scientific endorsement for or use of these products, mainly the development of mouthwashes with a preventive and alternative means of reducing bacterial load in the oral cavity of the individual.

\section{Conflict of interest}

The authors declare that they do not have any conflict of interest regarding the study topic.

\section{Ethical aspects}

The authors declare that they have abided with ethical guidelines regarding the study.

\section{BIBILOGRAPHIC REFERENCES}

Akthar, M.S.; Birhanu, D. \& Tanweer, A. 2014. Antimicrobial activity of essential oils extracted from medicinal plants against the pathogenic microorganisms: a review. Journal of Social Issues, 2350: 65-88.
Albado, P.E.; Saez, F.G. \& Grabiel, A.S. 2001. Composición química y actividad antibacteriana del aceite esencial del Origanum vulgare (orégano). Revista Médica Herediana, 12: 1619.

Almas, K. \& Al, Z.Z. 2004. The immediate antimicrobial effect of a toothbrush and miswak on cariogenic bacteria: a clinical study. The Journal of Contemporary Dental Practice, 5: 105-114.

Al, S.S \& Kasi, M. 2012. Anti-biofilm activity of Salvadora persica on cariogenic isolates of Streptococcus mutans: in vitro and molecular docking studies. Biofouling, 28: 29-38.

Alarcón, M.; Fraile, S.; Michelangeli, F.; Contreras, M. \& Fernández, R. 2016. Evaluación in vitro de dos extractos de Aloe vera en bacterias patógenas. Salus, 20: 41-46.

Aparicio, Z.R.; Rojas-Fermín, L.; Velasco, J.; Usubillaga, A.; Sosa, M. \& Rojas, J. 2019. Caracterización química y actividad antimicrobiana del aceite esencial de las hojas de Libanothamnus neriifolius (Asteraceae). Revista peruana de biología, 26: 95-100.

Bernardino, E.A.; Morteo, L.T.; Naranjo, A.G.R.; Ruiz, M.M.; Uscanga, C.L.P. \& Hernández, G.R.C. 2019. Efectividad del cacao sobre el desarrollo del Biofilm en estudiantes de Odontologia 
Veracruz, generación 2018. Revista Mexicana de Medicina Forense y Ciencias de la Salud, 4: 45-49.

Borba, A.M. \& Macedo, M. 2006. Plantas medicinais usadas para a saúde bucal pela comunidade do bairro Santa Cruz, Chapada dos Guimaráes, MT, Brasil. Acta Botanica Brasilica, 20: 771782.

Borja, V. 2017. Efecto inhibitorio del extracto de manzanilla (Matricaria chamomilla), extracto de llantén (Plantago major L.) y la combinación del extracto de manzanilla y llantén comparado con la clorhexidina sobre cepa de Porphyromona gingivalis. Universidad Central del Ecuador. Facultad de Odontología, Tesis de Licenciatura Quito. pp. 17-29.

Bumb, S.S.; Bhaskar, D.J.; Agali, C.R.; Punia, H.; Gupta, V.; Singh, V. \& Chandra, S. 2014. Assessment of photodynamic therapy (PDT) in disinfection of deeper dentinal tubules in a root canal system: anin vitro study. Journal of Clinical and Diagnostic Research, 8: 59-67.

Boonyagul, S.; Banlunara, W.; Sangvanich, P. \& Thunyakitpisal, P. 2013. Effect of acemannan, an extracted polysaccharide from Aloe vera on BMSCs proliferation, differentiation, extracellular matrix synthesis, mineralization, and bone formation in a tooth extraction model. Odontology, 102: 310-317.

Dagli, N.; Dagli, R.; Mahmoud, R.S. \& Baroudi, K. 2015. Essential oils, their therapeutic properties, and implication in dentistry: A review. Journal of International Society of Preventive \& Community Dentistry, 5: 330-335.

Dalmasso, M.; De Haas, E.; Neve, H.; Strain, R.; Cousin, F.J.; Stockdale, S. R. \& Hill, C. 2015. Isolation of a novel phage with activity against Streptococcus mutans biofilms. PLoS One, 10: $1-18$.

De la Rosa, M. \& Prieto, J. 2010. Microbiología en ciencias de la salud. $2^{\mathrm{da}}$ Ed. Ed. Elsevier, pp. 84-101.

Dinesh, M.D.; Shaheena, A; Bari, K.K.; George, N. \& Meenatchisundaram, S. 2016. Preliminary screening of Anticariogenic properties of selected medicinal plants against Streptococcal dental caries. International Journal of Current Microbiology and Applied Sciences, 5: 699705.

Enrile de Rojas, F.J. \& Santos, A.A. 2005. Colutorios para el control de placa y gingivitis basados en la evidencia científica. Rcoe, 10: 445-452.

Escalante, P.M. \& Martínez, P.M. 2020. Sensibilidad de Listeria monocytogenes y Listeria ivanovii frente al aceite esencial de Cocos nucifera. Rebiol, 36: 38-44.

Falsetta, M.L.; Klein, M.I.; Colonne, P.M.; Scott-Anne, K.; Gregoire, S.; Pai, C.H. \& Koo, H. 2014. Symbiotic relationship between Streptococcus mutans and Candida albicans synergizes virulence of plaque biofilms in vivo. Infection and Immunity, 82: 1968-1981.

Fazio, M.L.S.; Paulino, L.G. \& Geromel, M.R. 2019. Potencial antibacteriano de mel in natura, produzido por Apis mellifera e Tetragonisca angustula, e própolis comercial. Revista Inter Ciência-IMES Catanduva, 1: 1-8.

García, P.E.; Marín, L.; Domènech, E.; Bernal, I.; Mañosa, M.; Zabana, Y. \& Gassull, M.A. 2007. Utilización de medicinas alternativas y consumo de drogas por pacientes con enfermedad inflamatoria intestinal. Medicina Clínica, 128: $45-48$.

Gursoy, H.; Ozcakir, T.C. \& Tanalp, J. 2013. Photodynamic therapy in dentistry : a literature review. Clinical oral investigations, 17: 11131125 .

Gunsolley, J.C. 2010. Clinical efficacy of antimicrobial mouthrinses. Journal of Dentistry, 38: Suppl. 1, S6-S10.

Gonçalves, E.D.A. 2013. Avaliação da eficácia antimicrobiana dos enxaguatórios bucais contendo como princípios ativos o triclosan, cloreto de cetilpiridínio e óleos essenciais Composição dos colutórios bucais comercialmente disponíveis. HU Revista, Juiz de Fora, 39: 45-50.

Jakubovics, N.S. 2015. Intermicrobial interactions as a driver for community composition and stratification of oral biofilms. Journal of Molecular Biology, 427: 3662-3675. 
Joy, A.; Vinson, B.; Anto, L.; Dinilkumar, M.; Wilson, S.; Simon, S. \& Godavarma, J. 2019. Antibacterial screening and phytochemical powder isolated from dorsal side of leaves of Cocos nucifera (Arecaceae). Journal of Pharmaceutical Sciences and Research, 11: 2555-2557.

Kaur, G.; Rajesh, S. \& Princy, S. 2015. Plausible drug targets in the Streptococcus mutans quorum sensing pathways to combat dental biofilms and associated risks. Indian journal of microbiology, 4: 349-356.

Karadağlıoğlu, Ö.İ.; Ulusoy, N.; Başer, K.H.C.; Hanoğlu, A. \& Şı, İ. 2019. Antibacterial activities of herbal toothpastes combined with essential oils against Streptococcus mutans. Pathogens, 8: 1420 .

Liu, Q.R.; Wang, W.; Qi, J.; Huang, Q. \& Xiao, J. 2019. Oregano essential oil loaded soybean polysaccharide films: Effect of pickering type immobilization on physical and antimicrobial properties. Food Hydrocolloids, 87: 165-172.

Lambert, R.J.W.; Skandamis, P.N.; Coote, P.J. \& Nychas, G.J. 2001. A study of the minimum inhibitory concentration and mode of action of oregano essential oil, thymol and carvacrol. Journal of Applied Microbiology, 91: 453-462.

López, D. 2015. Comparación de la eficacia entre enjuagues bucales de gluconate de clorhexidina al 0,12 y de manzanilla con bicarbonato de sodio, en pacientes con gingivitis inducida por placa bacteriana. Universidad de Las Américas. Facultad de Odontología, Tesis de Licenciatura.

Maheswari, P.; Ponnusamy, S.; Harish, S.; Muthamizhchelvan, C. \& Hayakawa, Y. 2020. Syntheses and characterization of Syzygium aromaticum, Elettaria cardamomum and Cinnamomum verum modified $\mathrm{TiO}_{2}$ and their biological applications. Materials Science in Semiconductor Processing, 105: 104-107.

Mariani M.; Jaimes G. \& Fernandez, R. 2010. Efecto bacteriostático del extracto de semillas de cacaco (Theobroma cacaco L.) sobre el crecimiento de Streptococcus mutans in vitro. Revista científica facultad de odontología Universidad de Carabobo, 11: 15-22.
Mayta F.; Sacsaquispe S.; Ceccarelli J. \& Alania J. 2012. Propóleo peruano: Una nueva alternativa terapéutica antimicrobiana en estomatología. Revista Estomatológica Herediana 22: 50-58.

Moreno, A.; Cañada, A.; Antúnez, J.; Díaz, C. \& Pineda, A. 2011. Uso de la fitoterapia en 3 Clínicas Estomatológicas de Santiago de Cuba. Medisan, 15: 489-494.

Moreno, G.S.E.; Chávez, V. \& Brisset, D. 2020. Efecto del extracto etanólico de Moringa oleifera sobre la supervivencia de Listeria monocytogenes ATCC 19115 in vitro Universidad Nacional de Trujillo. Tesis de Microbiología y Parasitología.

Oda, Y.; Hayashi, F. \& Okada, M. 2015. Longitudinal study of dental caries incidence associated with Streptococcus mutans and Streptococcus sobrinus in patients with intellectual disabilities. BMC Oral Health, 15: 102-106.

Pérez, A.C.; Salvatierra, M.E.S. \& Delgado, D.R. 2020. Efecto antimicrobiano del aceite esencial de Orégano frente a Listeria monocytogenes y Staphylococcus aureus. Revista de Investigaciones Altoandinas, 22: 25-33.

Ramsay, E.I.; Rao, S.; Madathil, L.; Hegde, S.K.; BaligaRao, M.P.; George, T. \& Baliga, M.S. 2019. Honey in oral health and care: A mini review. Journal of Oral Biosciences, 61: 32-36.

Radünz, M.; da Trindade, M.L.M.; Camargo, T.M.; Radünz, A.L.; Borges, C.D.; Gandra, E. A. \& Helbig, E. 2019. Antimicrobial and antioxidant activity of unencapsulated and encapsulated clove (Syzygium aromaticum, L.) essential oil. Food Chemistry, 276: 180-186.

Rasooli, I.; Shayegh, S. \& Astaneh, S.D.A. 2009. The effect of Mentha spicata and Eucalyptus camaldulensis essential oils on dental biofilm. International journal of dental hygiene, 7: 196-203.

Reyes, K.B.; Ramos-Perfecto, D.; Luna, A.C.; Botello, C.P.; Paredes, D.D. \& Macedo, J.C. R. 2018. Efecto antibacteriano in vitro del extracto de Stevia rebaudiana sobre Streptococcus sanguinis y Actinomyces viscosus, bacterias iniciadoras en la formación de biopelícula dental. Odontología Sanmarquina, 21: 21-25. 
Ricatto, L.G.O.; Conrado, L.A.L.; Turssi, C.P.; França, F.M.G.; Basting, R.T. \& Amaral, F. L.B. 2014. Comparative evaluation of photodynamic therapy using LASER or light emitting diode on cariogenic bacteria: an in vitro study. European Journal of Dentistry, 8: 509-514.

Romero, Y. 2013. Determinación in vitro del efecto antibacteriano de la miel de la abeja común (Apis mellifera) y de la abeja angelita (Tetragonisca angustula) ante el Staphylococcus aureus coagulasa positivo. Revista Científica Agroecosistemas, 19:38-42.

Saha, M. \& Bandyopadhyay, P.K. 2019. Green biosynthesis of silver nanoparticle using Garlic, Allium sativum with reference to its antimicrobial activity against the pathogenic strain of Bacillus sp. and Pseudomonas sp. infecting Goldfish, Carassius auratus. Proceedings of the Zoological Society, 72: 180-186.

Sánchez, J. 2017. Eficacia antibacteriana in vitro del extracto etanólico de propóleo versus el aceite esencial de Origanum vulgare "orégano" sobre Streptococcus mutans". Tesis de grado. Universidad Privada de Tacna.

Santos, A. 2003. Evidence-based control of plaque and gingivitis. Journal of clinical periodontology, 30: 13-16.

Sedgley, C.; Buck, G. \& Appelbe, O. 2006. Prevalence of Enterococcus faecalis at multiple oral sites in endodontic patients using culture and PCR. Journal of Endodontics, 32: 104-109.

Schencke, C.; Vásquez, B.; Sandoval, C. \& Del Sol, M. 2016. El rol de la miel en los procesos morfofisiológicos de reparación de heridas. International Journal of Morphology, 34: 385395.
Shan, B.; Cai, Y.Z.; Brooks, J.D. \& Corke, H. 2011. Potential application of spice and herb extracts o natural preservatives in cheese. Journal of Medicinal Food, 14:284-290.

Shon, H.Y.; Son, K.H.; Kwon, C.S.; Kwon, G.S. \& Kang, S. S. 2004. Antimicrobial and Cytotoxic Activity of 18 prenylated flavonoids isolated from medicinal plants: Morus alba L., Morus mongolica Schneider, Broussnetia papyrifera (L.) Vent, Sophora flavescens Ait and Echinosophora koreensis Nakai. Phytomedicine, 11: 666-672.

Tiwari, B.S.; Ankola, A.V.; Sankeshwari, R.M.; Bolmal, U. \& Kashyap, B.R. 2018. Comparison of antibacterial efficacy of aqueous suspension, alcoholic extract and their combination of Stevia rebaudiana against two cariogenic organismsan in-vitro study. International journal of life sciences scientific research, 4: 1946-1951.

Wang, Q.Q.; Zhang, C.F.; Chu, C.H. \& Zhu, X.F. 2012. Prevalence of Enterococcus faecalis in saliva and filled root canals of teeth associated with apical periodontitis. International journal of oral science, 4: 19-23.

Xu, X.; Zhou, Z.; Xue D. \& Christine, D. 2011. The tea catechin epigallocatechin gallate suppresses cariogenic virulence factors of Streptococcus mutans. Antimicrobial agents and chemotherapy, 55: 1229-1236.

Zhang, C.; Du, J. \& Peng, Z. 2015. Correlation between Enterococcus faecalis and persistent intraradicular infection compared with primary intraradicular infection: A systematic review. Journal of Endodontics, 41: 1-7.

Received May 7, 2020.

Accepted June 20, 2020. 